\title{
PENGARUH CORPORATE SOCIAL RESPONSIBILITY DAN PERENCANAAN PAJAK TERHADAP NILAI PERUSAHAAN
}

\author{
Indra Iman Sumantri ${ }^{1^{*}}$, Intan Ayu Andini ${ }^{2}$ \\ Dosen Universitas Pamulang \\ email: imansumantri.indra@unpam.ac.id
}

\begin{abstract}
This study aims to determine and provide empirical evidence about the influence of Corporate Social Responsibility and Tax Planning on Company Value in agricultural sector manufacturing companies listed on the Indonesia Stock Exchange in the period 2014-2017. The number of samples used in this study are agricultural sector manufacturing companies listed on the Indonesia Stock Exchange (BEI) and published a complete financial report in 2014-2017 with 18 sample companies obtained using the purposive sampling method. The independent variable of this study is Corporate Social Responsibility measured by calculating the index according to GRI4, Tax Planning which is measured by calculating the effective tax rate, and company value measured by calculating the book price.

The results of the study were based on a hypothesis test with a significant level of 5\%, the results of this study concluded: Corporate Social Responsibility does not affect the value of the company. Tax planning affects the value of the company. Immediately (together) the variable Corporate Social Responsibility and Tax Planning have a significant effect on Company Value.
\end{abstract}

Keywords: Corporate Social Responsibility, Tax Planning, Company Value

\section{PENDAHULUAN}

Nilai perusahaan adalah persepsi investor terhadap perusahaan, yang sering dikaitkan dengan harga saham, karena harga saham saat ini mencerminkan penilaian investor terhadap perusahaan di masa yang akan datang. Jika perusahaan mengambil keputusan yang buruk maka harga saham akan turun. Oleh karena itu , tujuan manajemen adalah mengambil keputusan yang bisa menaikan harga saham, karena ini akan menghasilkan kekayaan bagi pemegang saham, sehingga akan meningkatkan nilai perusahaan (Brigham dan Houston, $2010: 8$ )

Nilai perusahaan yang sudah go public tercermin pada harga saham perusahaan, untuk memaksimumkan nilai perusahaan memiliki arti yang luas dari pada memaksimumkan laba perusahaan (Margaretha, 2014). Jika ingin memaksimalkan nilai suatu perusahaan, manajemen harus memanfaatkan kekuatan yang ada dan memperbaiki kelemahan pada perusahaan tersebut. Analisis keuangan membantu manajemen dalam mengidentifikasi kelemahan dan mengambil langkah-langkah perbaikan.

Kemudian Tanggung jawab sosial perusahaan atau Corporate Social Responsibility atau (CSR) sebagai sebuah gagasan yang menjadikan perusahaan tidak lagi dihadapkan pada tanggung jawab yang berpijak pada single bottom line, yaitu nilai perusahaan (corporate value) yang direfleksikan dalam kondisi keuangannya saja. Akan tetapi yanggung jawab sosial harus berpijak pada triple bottom lines. Konsep triple bottom lines yaitu sebuah konsep pembangunan berkelanjutan (sustainable development) pada aspek keuangan, aspek sosial, aspek lingkungan yaitu people, profit, dan planet (Rachman, Efendi, dan Wicaksana 2011:12). Konsep CSR mengatakan bahwa tanggung jawab perusahaan tidak hanya terhadap pemiliknya atau pemegang saham saja tetapi terhadap para stakeholders yang terkait dan/atau terkena dampak dari keberadaan perusahaan. Perusahaan yang menjalankan CSR akan memperlihatkan dampaknya terhadap kondisi sosial dan lingkungan dan berupaya agar dampaknya positif.

Selanjutnya, Perusahaan yang ingin melakukan perencanaan pajak harus memenuhi tiga hal tersebut. Kriteria pertama perencanaan pajak tidak boleh dilakukan secara illegal karena pada hakikatnya hanya melakukan penghematan pajak dengan cara yang baik dan benar. 
Kriteria kedua yaitu secara bisnis masuk akal, perusahaan kecil yang bergerak dalam bidang perdagangan memiliki karyawan yang banyak dan asset yang banyak. Hal tersebut tidak masuk akal karena pada umumnya perusahaan kecil hanya memiliki karyawan sedikit dan asset yang tidak cukup banyak sehingga dapat dikatakan tidak ideal untuk dilakukan perencanaan pajak yang baik. Kriteria ketiga yaitu bukti pendukung memadai, sebagai contoh perusahaan manufaktur melakukan penjualan kepada konsumen, pada saat barang dijual secara tunai sertakan kwitansi kepada konsumen sebagai bukti pembelian.

Maka atas fenomena diatas, penulis tertarik untuk melakukan penelitian yang berjudul "Pengaruh Corporate Social Responsibility dan Perencanaan Pajak Terhadap Nilai Perusahaan (Studi Empiris pada perusahaan Manufaktir Sektor Agriculture yang Terdaftar di Bursa Efek Indonesia Periode 2014-2017)"

\section{TINJAUAN PUSTAKA}

Stakeholders Theory membahas mengenai konsep tanggung jawab sosial perusahaan telah mulai dikenal sejak awal 1970-an, yang secara umum dikenal dengan stakeholder theory artinya sebagai kumpulan kebijakan dan praktik yang berhubungan dengan stakeholder, nilainilai, pemenuhan ketentuan hukum, penghargaan masyarakat dan lingkungan, serta komitmen dunia usaha untuk berkontribusi dalam pembangunan secara berkelanjutan.

Teori legitimasi berhubungan erat dengan teori stakeholder. Teori legitimasi menyatakan bahwa organisasi secara berkelanjutan mencari cara untuk menjamin operasi mereka berada dalam batas dan norma yang berlaku di masyarakat (Deegan, 2004). Menurut Deegan (2004), dalam perspektif teori legitimasi, suatu perusahaan akan secara sukarela melaporkan aktifitasnya jika manajemen menganggap bahwa hal ini adalah yang diharapkan komunitas.

\section{Metode Perhitungan Nilai Perusahaan}

Pengukuran Nilai Perusahaan dalam rasio penilaian perusahaan menurut Sugeng Rohmadi,(2018:43), rasio penilaian terdiri dari: Price Earning Ratio (PER), Price to Book Value (PBV) dan Tobin's Q. Dari ketiga rasio pengukuran tersebut peneliti tertarik untuk menggunakan PBV. Alasan kenapa peneliti menggunakan Nilai perusahaan dapat diukur dengan PBV (price book value) merupakan rasio pasar yang digunakan untuk mengukur kinerja harga pasar saham terhadap nilai bukunya.

\section{Pengungkapan Corporate Sosial Responsibility (CSR)}

Standar pengungkapan CSR yang berkembang di Indonesia adalah merujuk standar yang dikembangkan oleh Global Reporting Initiatives (GRI). Standar GRI dipilih karena lebih memfokuskan pada standar pengungkapan berbagai kinerja ekonomi, sosial, dan lingkungan perusahaan dengan tujuan untuk meningkatkan kualitas, teliti, dan pemanfaatan laporan berkelanjutan (sustainability reporting). Dalam GRI terdapat 91 indikator pengungkapan yang terbagi lagi dalam 3 kategori dan 4 sub bab kategori yaitu kategori ekonomi, lingkungan, dan sosial. Didalam kategori sosial terdapat 4 sub kategori yang terdiri dari, sub bab praktek ketenagakerjaan dan kenyamanan bekerja, hak asasi manusia, masyarakat, dan tanggung jawab atas produk. Penilaian indikator ini dengan cara memberi skor 1 jika perusahaan mengungkapkan 1 (satu) item saja. Namun jika item tidak diungkapkan maka diberi skor 0 (nol).

\section{Effective Tax Rate (ETR)}

Perencanaan pajak merupakan langkah pertama ketika melaksanakan manajemen pajak dan proses mengorganisasi dari usaha dan kelompok wajib pajak agar bisa meminimumkan kewajiban dari hutang pajak serta beban pajak perusahaan, selama masih diperbolehkan dalam peraturan perundang-undangan. Variabel ini diukur menggunakan Effective Tax Rate atau ETR seperti dalam penelitian Khotimah (2013). Variabel ini diperoleh dari laporan keuangan tahunan perusahaan. 


\section{METODE}

Penelitian merupakan suatu tempat atau wilayah dimana peneliti tersebut adan dilakukan. Lokasi penelitian ini dilakukan di Bursa Efek Indonesia (BEI), data yang diperoleh dengan mengakses data melalui website www.idx.co.id atau situs resmi dari perusahaan.

Variabel dependen dalam penelitian ini adalah nilai perusahaan. Nilai perusahaan yang sudah go public tercermin dalam harga pasar saham perusahaan sedangkan pengertian nilai perusahaan yang belum go public nilainya terealisasi apabila perusahaan akan dijual (total aktiva dan prospek perusahaan, risiko usaha,lingkngan usaha, dan lain lain). Nilai perusahaan diukur dengan menggunakan rasio Price Book Value (PBV). Alasan menggunakan rasio Price Book Value (PBV) karena merupakan rasio pasar yang digunakan untuk mengukur kinerja harga pasar saham terhadap nilai bukunya.

Variabel independen (X1) dari penelitian ini adalah Corporate Social Responsibility. Tanggung jawab sosial perusahaan merupakan satu bentuk tindakan yang berangkat dari pertimbangan etis perusahaan yang di arahkan untuk meningkatkan ekonomi, yang di barengi dengan peningkatan kualitas hidup bagi karyawan berikut keluarganya, serta sekaligus peningkatan kualitas hidup masyarakat sekitar dan masyarakat secara lebih luas. Dalam GRI G4 terdapat 91 indikator pengungkapan yang terbagi lagi dalam 3 kategori yaitu Ekonomi, Lingkungan, dan Sosial. Sedangkan pada kategori sosial terdapat 4 Sub-Kategori antara lain yaitu Sub-kategori praktek ketenagakerjaan dan kenyamanan bekerja, Sub-kategori hak asasi manusia, Sub-kategori masyarakat, dan Sub-kategori tanggungjawab atas produk. Penilaian indikator ini dengan cara memberi skor 1 jika perusahaan mengungkapkan 1 (satu) item saja. Namun jika item tidak diungkapkan maka diberi skor 0 (nol).

Variabel independen (X2) dari penelitian ini adalah perencanaan pajak. Perencanaan pajak yaitu minimalisasi penghasilan kena pajak dalam tahun berjalan dapat diinterpretasikan sebagai maksimalisasi penghasilan kena pajak atau pajak penghasilan yang terhutang dalam tahun berjalan dapat dilakukan dengan mengidentifikasi dan memanfaatkan tarif pajak yang revelan dalam membuat keputusankeputusan menyangkut aktivitas operasi, investasi dan pendanaan. Perencanaan pajak ini diukur dengan menggunakan rasio Tarif Pajak Efektif (Effective Tax Rate, ETR). Tarif pajak efektif ini merupakan pembagian beban pajak kini atau beban pajak dengan laba sebelum pajak.

Populasi dalam penelitian ini adalah perusahaan sektor Agriculture yang terdaftar di Bursa Efek Indonesia periode 2014 - 2017. Jumlah populasi adalah sebanyak 22 perusahaan dan tidak semua populasi ini akan menjadi objek penelitian, sehingga perlu dilakukan pengambilan sampel lebih lanjut.

Pemilihan sampel dilakukan dengan menggunakan teknik purposive sampling, alasan pemilihan sampel dengan menggunakan purposive sampling adalah karena tidak semua sampel memiliki kriteria sesuai dengan yang telah penulis tentukan. Berdasarkan teknik tersebut, maka diperoleh 18 perusahaan sebagai sampel penelitian. Teknik analisis data yang digunakan dalam penelitian ini adalah uji asumsi klasik, dan uji hipotesis.

\section{HASIL DAN PEMBAHASAN}

Dapat diketahui bahwa terdapat 3 variabel penelitian, yaitu Corporate Social Responsibility, Perencanaan Pajak, dan Nilai Perusahaan. hasil pengolahan data dengan bantuan SPSS (Statistic Product and Service Solution) hasil pengujian statistik deskriptif dapat dilihat pada tabel berikut: 
Tabel Hasil Uji Statistik Deskriptif

\begin{tabular}{lr|r|r|r|r} 
& & & & \multicolumn{2}{l}{$\begin{array}{l}\text { Std. } \\
\text { Deviation }\end{array}$} \\
\hline & N & Minimum & Maximum & Mean & Descriptive Statistics \\
\hline $\begin{array}{l}\text { Corpotare Social } \\
\text { Responsibility }\end{array}$ & 72 &, 29 &, 71 &, 4986 &, 13723 \\
\hline $\begin{array}{l}\text { Perencanaan Pajak } \\
\text { Nilai Perusahaan }\end{array}$ & 72 & $-1,03$ & 3,96 &, 6272 &, 99052 \\
\hline Valid N (listwise) & 72 &, 02 & 6,11 & 1,4044 & 1,26592 \\
\hline
\end{tabular}

Sumber : Data Dioleh menggunakan SPSS Versi 25, 2019

Berdasarkan hasil uji statistik deskriptif pada tabel 4.3 menunjukan bahwa banyaknya jumlah sampel penelitian $(\mathrm{N})$ adalah 72 . Jumlah tersebut merupakan jumlah perusahaan manufaktur sektor Agriculture yang terdaftar di Bursa Efek Indonesia tahun pengamatan dari tahun 2014 hingga 2017. Adapun statistik deskriptif dapat dijelaskan sebagai berikut:

1. Dari hasil pengujian statistik deskriptif pada tabel 4.3 diatas bahwa Corporate Social Responsibility memiliki jumlah sampel $(\mathrm{N})$ sebanyak 72 perusahaan, dengan nilai minimum 0,29 yaitu pada PT. Central Proteina Prima Tbk (CPRO) tahun 2014-2015 dan PT Bakrie Sumatera Plantations Tbk (UNSP) pada tahun 2015. Nilai maximum 0,71 yaitu pada PT Sampoerna Agro Tbk (SGRO) tahun 2016, dan nilai rata-rata (mean) corporate social responsibility sebesar 0,4986 dan simpangan baku (standar deviation) 0,13723. Hal ini menunjukan bahwa berarti nilai mean lebih besar daripada standar deviasi sehingga mengindikasi bahwa hasil yang baik. Sebab standar deviasi merupakan cerminan penyimpangan yang sangat tinggi sehingga penyebaran data menunjukan hasil yang baik

2. Dari hasil pengujian statistik deskriptif pada tabel 4.3 diatas bahwa perencanaan pajak memiliki jumlah sampel $(\mathrm{N})$ sebanyak 72 perusahaan, dengan nilai minimum $-0,03$ yaitu pada PT Gozco Plantations Tbk tahun 2016, dan nilai maximum sebesar 3,96 pada PT Sawit Sumbermas Sarana Tbk (SSMS) Tahun 2014, nilai rata-rata (mean) perencanaan pajak sebesar 0,6272 dan simpangan baku (standar deviation) sebesar 0,99052. Hal ini berarti mean lebih kecil daripada standar deviasi sehingga mengindikasikan hal yang kurang baik dan penyebaran datanya kurang baik.

3. Dari hasil pengujian statistik deskriptif pada tabel 4.3 diatas bahwa Nilai Perusahaan memiliki jumlah sampel $(\mathrm{N})$ sebanyak 72 perusahaan, dengan nilai minimum 0,02 yaitu PT Bumi Teknokultura Unggul Tbk (BTEK) tahun 2014, dan nilai maximum 6,11 yaitu pada PT Sawit Sumbermas Sarana Tbk (SSMS) Tahun 2015, nilai rata-rata (mean) sebesar 1,4044 dan simpangan baku (standar deviation) 1,26592. Hal ini berarti nilai mean lebih besar dari pada standar deviasi sehingga mengindikasikan hasil yang baik dan menyebaran data yang bagus.

\section{Uji Normalitas}

Uji normalitas data digunakan untuk mengetahui apakah data-data telah terdistribusi normal. Uji normalitas dapat dilakukan dengan cara menggunakan grafik normal probability plot dan uji statistik kolmogrov-smirno. Hasil uji normalitas dalam penelitian ini adalah sebagai berikut : 


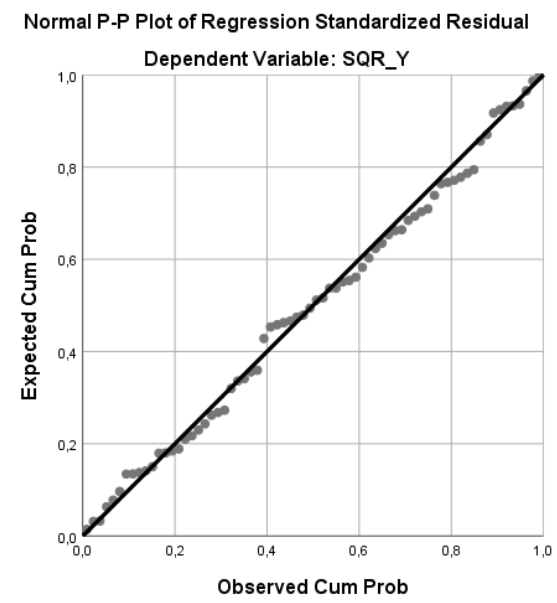

Sumber: data diolah menggunakan SPSS versi 25, 2019

Gambar Hasil Uji Normalitas Probability Plot

Dengan melihat gambar grafik normal Probability Plot dapat disimpulkan bahwa pada grafik normal Probability Plot terlihat titik menyebar disekitar garis diagonal, serta penyebaran mengikuti garis diagonal.

\section{Tabel Hasil Uji Normalitas}

One-Sample Kolmogorov-Smirnov Test

\begin{tabular}{|l|l|r|}
\hline \multicolumn{2}{|l|}{} & \multicolumn{1}{l|}{$\begin{array}{l}\text { Unstandardized } \\
\text { Residual }\end{array}$} \\
\hline \multirow{2}{|l|}{$N$} & 70 \\
\hline \multirow{2}{*}{ Normal Parameters ${ }^{\mathrm{a}, \mathrm{b}}$} & Mean &, 0000000 \\
\cline { 2 - 3 } & Std. Deviation &, 44028402 \\
\hline \multirow{2}{*}{ Most Extreme Differences } & Absolute &, 059 \\
\cline { 2 - 3 } & Positive &,- 059 \\
\cline { 2 - 3 } & Negative &, 059 \\
\hline Test Statistic & &, $200^{\mathrm{c}, \mathrm{d}}$ \\
\hline Asymp. Sig. (2-tailed) & & -053 \\
\hline
\end{tabular}
a. Test distribution is Normal.
b. Calculated from data.
c. Lilliefors Significance Correction.
d. This is a lower bound of the true significance.

Sedangkan dasar pengambilan keputusan uji kolmogrof-smirnov adalah jika nilai signifikan asym.sig (2-tailed) lebih besar sama dengan alpha $(0,05)$ maka data terdistribusi normal dan jika angka signifikansi asymp.sig (2-tailed) lebih kecil dari alpha $(0,05)$ maka data tidak terdistribusi normal. Besarnya nilai symp.sig (2-tailed) dalam penelitian ini adalah 0,200 lebih besar dari alpha $(0,05)$, hal ini berarti data residual terdistribusi secara normal. 


\section{Uji Multikolinearitas}

Menurut Ghozali (2016:103) uji multikolinieritas bertujuan untuk menguji apakah model regresi ditemukan adanya korelasi antar variabel bebas (independen). Model regresi yang baik seharusnya tidak terjadi korelasi diantara variabel independen. Berikut adalah hasil uji multikolineritas dalam penelitian ini.

\section{Tabel Hasil Uji Multikolinearitas}

\begin{tabular}{|c|c|c|c|c|c|c|c|c|}
\hline \multicolumn{9}{|c|}{ Coefficients ${ }^{\mathrm{a}}$} \\
\hline \multirow{2}{*}{\multicolumn{2}{|c|}{ Model }} & \multicolumn{2}{|c|}{$\begin{array}{l}\text { Unstandardized } \\
\text { Coefficients }\end{array}$} & \multirow{2}{*}{$\begin{array}{c}\text { Standardized } \\
\text { Coefficients } \\
\text { Beta }\end{array}$} & \multirow{3}{*}{$\frac{\mathrm{t}}{0.930}$} & \multirow{3}{*}{$\begin{array}{c}\text { Sig. } \\
0,356\end{array}$} & \multicolumn{2}{|c|}{$\begin{array}{l}\text { Collinearity } \\
\text { Statistics }\end{array}$} \\
\hline & & B & $\begin{array}{l}\text { Std. } \\
\text { Error }\end{array}$ & & & & Tolerance & VIF \\
\hline \multirow[t]{3}{*}{1} & (Constant) & 0,452 & 0,486 & & & & & \\
\hline & $\begin{array}{l}\text { Corporate } \\
\text { Social } \\
\text { Responsibility }\end{array}$ & 0,898 & 0,898 & 0,097 & 1,000 & 0,321 & 0,950 & 1,052 \\
\hline & $\begin{array}{l}\text { Perencanaan } \\
\text { Pajak }\end{array}$ & 0,805 & 0,124 & 0,630 & 6,469 & 0,000 & 0,950 & 1,052 \\
\hline
\end{tabular}

a. Dependent Variable: Nilai Perusahaan

Sumber : Data diolah menggunakan SPSS versi 25, 2019

Berdasarkan tabel diatas angka yang didapat dalam kolom tolerance menunjukan corporate social responsibility 0,950, perencanaan pajak 0,950 secara keseluruhan variabel independen memiliki nilai lebih besar dari 0,10 yang artinya tidak terdapat korelasi antar variabel independen. Sedangkan angka didapat dalam kolom VIF untuk corporate social responsibility 1,052 dan perencanaan pajak 1,052 yang artinya lebih kecil dari 10. Maka dapat dinyatakan bahwa model ini terbebas dari multikoliearitas antar variabel independen

\section{Uji Heterokedasitas}

Menurut Ghozali (2016:134) uji heteroskedastisitas bertujuan untuk menguji apakah dalam model regresi terjadi ketidaksamaan variance dari residual satu pengamatan ke pengamatan yang lain. Jika variance dari residual satu pengamatan ke pengamatan lain tetap, maka disebut homoskedastisitas dan jika berbeda disebut heteroskedastisitas. Untuk mendeteksi adanya heterokedasitas dalam penelitian ini menggunakan grafik scatterplot. Berikut adalah hasil uji heterokedasitas dengan grafik:

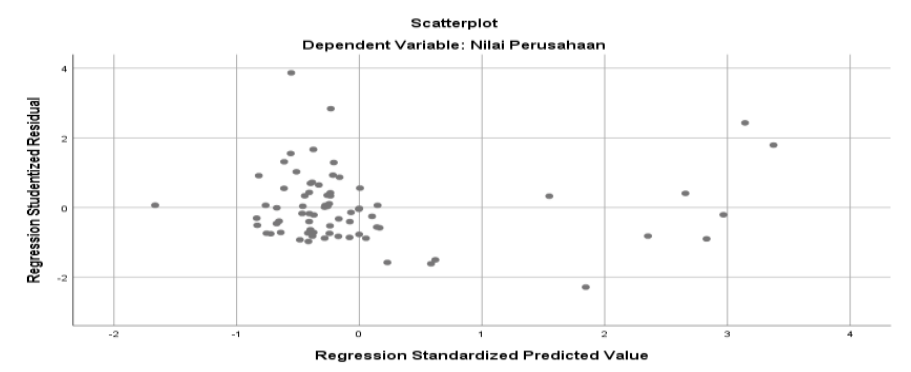

Sumber: Data diolah menggunakan SPSS versi 25, 2019

\section{Gambar Hasil Uji Heterokedasitas Scatterplot}

Dari gambar grafik scatterplot diatas dapat dilihat bahwa titik-titik yang menyebar dan tidak membentuk pola. Terlihat bahwa titik-titik menyebar secara acak diatas maupun dibawah angka 0 pada sumbu Y. Hal ini dapat disimpulkan bahwa tidak terjadi masalah heterokedasitas pada model regresi.

\section{Uji autokorelasi}

Uji autokorelasi bertujuan menguji apakah dalam model regresi linear ada korelasi antara kesalahan pengganggu pada periode $\mathrm{t}$ dengan kesalahan pengganggu pada periode $\mathrm{t}-1$ 
(sebelumnya). Jika terjadi korelasi, maka dinamakan ada problem autokorelasi. Autokorelasi muncul karena observasi yang berurutan sepanjang waktu berkaitan satu sama lainnya (Ghozali, 2011:110). Metode yang dipakai dalam penelitian ini adalah dengan uji Durbin-Watson (DW test). Hasil pengujian dengan uji Durbin Watson dapat dilihat sebagai berikut :

Tabel Hasil Uji Autokorelasi

\begin{tabular}{|c|c|c|c|c|c|}
\hline \multicolumn{6}{|c|}{ Model Summary $^{b}$} \\
\hline Model & $\mathrm{R}$ & R Square & $\begin{array}{l}\text { Adjusted R } \\
\text { Square }\end{array}$ & $\begin{array}{l}\text { Std. Error of } \\
\text { the Estimate }\end{array}$ & $\begin{array}{l}\text { Durbin- } \\
\text { Watson }\end{array}$ \\
\hline 1 &, $293^{\mathrm{a}}$ &, 086 & ,073 & ,96557378 & 1,643 \\
\hline
\end{tabular}

a. Predictors: (Constant), Lag_Residual_1

b. Dependent Variable: Unstandardized Residual

Sumber : Data diolah menggunakan SPSS versi 25, 2019

Berdasarkan tabel diatas, diketahui bahwa nilai Durbin Watson (d) sebesar 1,643. Karena berasa diantara -2 sampai +2 berarti data yang digunakan tiadak terjadi autokorelasi karena sesuai dengan kriteria tersebut.

\section{Uji Hipotesis}

Uji Hipotesis merupakan pernyataan-pernyataan yang menggambarkan suatu hubungan antara dua variabel yang berkaitan dengan suatu kasus tertentu dan merupakan anggapan sementara yang perlu diuji benar atau tidak benar tentang dugaan dalam suatu penelitian serta memiliki manfaat bagi proses penelitian agar efektif dan efisien.

\section{Uji Regresi Linear Berganda}

Uji Regresi Linear Berganda bertujuan melihat pengaruh antara variabel independen dan variabel dependen dengan skala pengukuran rasio dalam suatu persamaan linier, dalam penelitian ini digunakan analisis regeresi berganda. Analisi regresi sedehana digunakan untuk mengetahui Corporate Social Responsibility (X1) dan Perencanaan Pajak (X2), terhadap Nilai Perusahaan perusahaan (Y).

Tabel Hasil Uji Regresi Linear berganda

Coefficients $^{\mathrm{a}}$

\begin{tabular}{|c|c|c|c|c|c|c|}
\hline \multirow{2}{*}{\multicolumn{2}{|c|}{ Model }} & \multicolumn{2}{|c|}{$\begin{array}{l}\text { Unstandardized } \\
\text { Coefficients }\end{array}$} & \multirow{2}{*}{$\begin{array}{l}\text { Standardized } \\
\text { Coefficients }\end{array}$} & \multirow[t]{2}{*}{$\mathrm{T}$} & \multirow[t]{2}{*}{ Sig. } \\
\hline & & B & $\begin{array}{l}\text { Std. } \\
\text { Error }\end{array}$ & & & \\
\hline \multirow{3}{*}{1} & (Constant) & 0,452 & 0,486 & & 0,93 & 0,356 \\
\hline & $\begin{array}{l}\text { Corporate Social } \\
\text { Responsibility }\end{array}$ & 0,898 & 0,898 & 0,097 & 1,000 & 0,321 \\
\hline & Perencanaan Pajak & 0,805 & 0,124 & 0,63 & 6,469 & 0 \\
\hline
\end{tabular}

a. Dependent Variable: Nilai Perusahaan

Sumber : Data diolah menggunakan SPSS versi 25, 2019

Berdasarkan tabel 5 diatas dapat dianalisis model regresi sebagai berikut:

$$
Y=a+\beta X 1+\beta X 2+e
$$




$$
Y=0,05+0,898 X 1+0,805 X 2+e
$$

Dari persamaan tersebut menunjukan bahwa:

1. Kontanta (Nilai Perusahaan) sebesar 0,452 yang berarti jika X1 (Corporate Social Responsibility) dan X2 (Perencanaan Pajak) nilainya adalah 0 maka Y (Nilai Perusahaan nilainya sebesar 0,452 )

2. Variabel X1 yang merupakan koefisien regresi dari (Corporte Social Responsibility) sebesar 0,898 dengan arah koefisien positif. Artinya X1 (Corporate Social Responsibility) meningkat 1 satuan, maka Y (nilai perusahaan) meningkat sebesar 0,898 dengan catatan variabel lain dianggap konstan.

3. Variabel $\mathrm{X} 2$ yang merupakan koefisien regresi dari (Perencanaan Pajak) sebesar 0,805 dengan arah koefisien positif. Artinya X2 (Perencanaan Pajak) meningkat 1 satuan, maka Y (nilai perusahaan) meningkat sebesar 0,805 dengan catatan variabel lain dianggap konstan.

\section{Uji Koefisien Korelasi}

Uji koefisien korelasi bertujuan untuk mengukur kekuatan asosiasi (hubungan) linear antar dua variabel. Korelasi tidak menunjukan hubungan fungsional atau dengan kata lain analisis korelasi tidak membedakan antara variabel dependen dengan variabel independen (Ghozali, 2013)

Interprestasi nilai kefisien korelasi dan kekuatan hubungan antara variabel Corporate Social Responsibility (X1), perencanaan pajak (X2), dan nilai perusahaan (Y) dengan hasil sebagai berikut :

Tabel Interprestasi Koefisien Korelasi

\begin{tabular}{|l|l|}
\hline Interval Koefisien & Tingkat Hubungan \\
\hline $0,00-0,199$ & Sangat Rendah \\
\hline $0,20-0,399$ & Rendah \\
\hline $0,40-0,599$ & Sedang \\
\hline $0,60-0,0799$ & Kuat \\
\hline $0,80-1,000$ & Sangat Kuat \\
\hline
\end{tabular}

(Sugiyono, 2012)

Dari tabel interprestasi koefisien korelasi maka dapat dihasilkan yang tertera dalam tabel diatas yaitu sebagai berikut :

Tabel Hasil Uji Koefisien Korelasi

\begin{tabular}{l|r|r|l|l|r|}
\hline & & & \multicolumn{1}{l}{ Modjusted R } \\
Model & R & R Square & Square & $\begin{array}{l}\text { Std. Error of the } \\
\text { Estimate }\end{array}$ & Durbin-Watson \\
\hline 1 &, $293^{\mathrm{a}}$ &, 086 &, 073 &, 96557378 & 1,643 \\
\hline
\end{tabular}
a. Predictors: (Constant), Lag_Residual_1
b. Dependent Variable: Unstandardized Residual

Sumber : Data diolah menggunakan SPSS versi 25, 2019

Berdasarkan tabel diatas, menunjukan hasil koefisien korelasi antara corporate social responsibility dan perencanaan pajak terjadap nilai perusahaan sebesar 0,293, karena berada pada interval koefisien $0,20-0,499$ maka dinyatakan tingkat hubungan rendah Koefisien Determinasi $\left(\mathbf{R}^{2}\right)$ 
Koefisien determinasi $\left(\mathrm{R}^{2}\right)$ bertujuan untuk melihat seberapa besar tingkat pengaruh variabel independen terhadap varabel dependen secara parsial digunakan koefisien determinasi. Koefisien determinasi merupakan kuadrat dari koefisien kolerasi sebagai ukuran untuk mengetahui kemampuan dari masing-masing varaibel yang digunkan. Dengan koefisien determinasi dapat diketahui besarnya kontribusi pengaruh variabel independen terhadap variabel dependen. Berikut tabel koefisien determinasi :

Tabel Hasil Uji Koefisien Determinasi $\left(\mathbf{R}^{2}\right)$

\begin{tabular}{|c|c|c|c|c|c|}
\hline \multicolumn{6}{|c|}{ Model Summary } \\
\hline Model & $\mathrm{R}$ & R Square & $\begin{array}{l}\text { Adjusted R } \\
\text { Square } \\
\end{array}$ & $\begin{array}{l}\text { Std. Error of the } \\
\text { Estimate }\end{array}$ & Durbin-Watson \\
\hline 1 &, $293^{a}$ & ,086 & ,073 & ,96557378 & 1,643 \\
\hline
\end{tabular}

a. Predictors: (Constant), Perencanaan Pajak, Corporate Social Responsibility

b. Dependent Variable: Unstandardized Residual

Sumber : Data diolah menggunakan SPSS versi 25, 2019

Berdasarkan tabel diatas, angka koefisien determinasi $\left(\mathrm{R}^{2}\right)$ Adjusted $R$ Square yang diperoleh adalah sebesar 0.073 atau 7,3\%. Hal ini menunjukan bahwa presentase pengaruh variabel independen (corporate social responsibility dan perencanaan pajak) terhadap variabel depanden (Nilai perusahaan) adalah sebesar 7,3\%. Sehingga variasi variabel independen yang digunakan dalam model penelitian (corporate social responsibility dan perencanaan pajak) mampu menjelaskan 7,3\% variansi variabel dependen (nilai perusahaan) sedangkan sisanya sebesar $92,7 \%$ dipengaruhi atau dijelaskan oleh variabel lain yang ada diluar model penelitian.

\section{Uji Statistik t (test)}

Uji statistik t (test) pada dasarnya menunjukan seberapa jauh pengaruh satu variabel independen secara individual dalam menerangkan variasi variabel dependen. Hipotesis nol (Ho) yang hendak diuji adalah apakah suatu parameter (bi) sama dengan nol (Ghozali, 2016:97)

Tabel Hasil Uji Statistik t (test) Coefficients $^{\mathrm{a}}$

\begin{tabular}{|c|c|c|c|c|c|c|}
\hline \multirow{2}{*}{\multicolumn{2}{|c|}{ Model }} & \multicolumn{2}{|c|}{$\begin{array}{l}\text { Unstandardized } \\
\text { Coefficients }\end{array}$} & \multirow{2}{*}{$\begin{array}{l}\text { Standardized } \\
\text { Coefficients } \\
\text { Beta } \\
\end{array}$} & \multirow[t]{2}{*}{$\mathrm{t}$} & \multirow[t]{2}{*}{ Sig. } \\
\hline & & B & Std. Error & & & \\
\hline \multirow{3}{*}{1} & (Constant) & 0,452 & 0,486 & & 0,93 & 0,356 \\
\hline & $\begin{array}{l}\text { Corporate Social } \\
\text { Responsibility }\end{array}$ & 0,898 & 0,898 & 0,097 & 1 & 0,321 \\
\hline & Perencanaan Pajak & 0,805 & 0,124 & 0,63 & 6,469 & 0 \\
\hline
\end{tabular}

a. Dependent Variable: Nilai Perusahaan

Sumber : Data diolah menggunakan SPSS versi 25, 2019

Hasil uji t pada tabel diatas. Maka dapat diperoleh hasil sebagai berikut:

1. Pengaruh Corporate Social Responsibility terhadap Nilai Perusahaan

Berdasarkan hasil uji parsial t diatas, dapat diketahui bahwa nilai $t_{\text {hitung }}$ corporate social responsibility yaitu sebesar 1,000 dengan nilai $\mathrm{t}_{\text {tabel }} 1,994$ dan nilai signifikan 0,321 atau lebih besar dari $\alpha=0,05(0,321>0,05)$ sehingga dapat disimpulkan $\mathrm{H}_{1}$ ditolak yang artinya Corpotare Social Responsibility tidak berpengaruh signifikan terhadap Nilai Perusahaan 
2. Pengaruh Perencanaan Pajak terhadap Nilai Perusahaan

Berdasarkan hasil uji parsial t diatas, dapat diketahui bahwa variabel Perencanaan Pajak memiliki $t_{\text {hitung }}$ sebesar 6,469 dengan nilai $t_{\text {tabel }} 1,994$ dan nilai signifikansi 0,000 atau lebih kecil dari $\alpha=0,05(0,00<0,05)$ sehingga dapat disimpulkan $\mathrm{H}_{2}$ diterima yang artinya Perencanaan Pajak Berpengaruh signifikan terhadap Nilai Perusahaan.

\section{Uji secara Simultan (Statistik F)}

Uji secara simultan (Statistik F) Menurut Ghozali (2016), pengujian ini bertujuan untuk membuktikan apakah variabel independen secara simultan (bersama-sama) mempunyai pengaruh terhadap variabel dependen. Apabila F hitung > F tabel, maka Ho ditolak dan Ha diterima, yang berarti variabel independen mempunyai pengaruh yang signifkan terhadap variabel dependen dengan menggunakan tingkat signifikan sebesar 5\%, jika nilai $\mathrm{F}$ hitung $>\mathrm{F}$ tabel maka secara bersama-sama seluruh variabel independen mempengaruhi variabel dependen. Berikut adalah hasil uji dari uji simultan F terdapat dalam tabel dibawah ini :

\section{Tabel Hasil Uji Simultan F}

ANOVA $^{\mathrm{a}}$

\begin{tabular}{ll|r|r|r|r|r} 
Model & & Sum of Squares & df & Mean Square & F & Sig. \\
\hline 1 & Regression & 43,087 & 2 & 21,544 & 21,028 &, $000^{\mathrm{b}}$ \\
\cline { 2 - 7 } & Residual & 70,694 & 69 & 1,025 & & \\
\hline Total & 113,781 & 71 & & & \\
\hline
\end{tabular}

a. Dependent Variable: Nilai Perusahaan

b. Predictors: (Constant), Perencanaan Pajak, Corpotare Social Responsibility

Sumber : Data diolah menggunakan SPSS versi 25, 2019

Berdasarkan hasil uji simultan $\mathrm{F}$ didapat nilai $\mathrm{f}_{\text {hitung }}$ sebesar 21,028 dengan tingkat kesalahan 5\% dimana df $\left(\mathrm{n}_{1}\right)$ 3-1 = 2 dan df $\left(\mathrm{n}_{2}\right)$ 72-3 = 69 maka diperoleh $\mathrm{f}_{\text {tabel }}$ df $\left(\mathrm{n}_{1}\right)$ dan df $\left(n_{2}\right) 69$ sebesar $f_{\text {hitung }}>f_{\text {tabel }}(21,028>3,12)$ dengan nilai signifikansi Nilai Perusahaan 0,000. Karena nilai signifikasi Nilai perusahaan lebih kecil dari $0,05(0,000<0,05)$, sehingga $\mathrm{H}_{3}$ diterima yang artinya Corporate Social Responsibility dan Perencanaan Pajak Berpengaruh terhadap Nilai Perusahaan

\section{Pembahasan}

Penelitian ini dilakukan dengan tujuan untuk menemukan bukti empiris apakah terdapat pengaruh signifikan antara Corporate Social Responsibility dan Perencanaan Pajak terhadap Nilai perussahaan pada perusahaan manufaktur sektor Agriculture yang terdaftar di Bursa Efek Indonesia periode 2014-2017. Penelitian ini dilakukan terhadap 18 perusahaan yang telah terpilih dengan metode puposive sampling dengan berbagai kriteria yang ditentukan. Hasil pengujian hipotesis yang dikembangkan dalam penelitian ini secara ringkas disajikan sebagai berikut :

\section{Hubungan Corporate Social Responsibility terhadap Nilai Perusahaan}

Hasil uji parsial $\mathrm{t}$ menjelaskan bahwa $\mathrm{H}_{1}$ diketahui variabel corporate social responsibility terhadap nilai perusahaan dapat diketahui nilai thitung sebesar 1,000 dengan nilai ttabel 1,994 dan nilai signifikansi 0,321 atau lebih besar dari $\alpha=0,05(0,321>0,05)$ sehingga dapat disimpulkan H1 ditolak yang artinya Corporate Social Responsibility tidak berpengaruh signifikan terhadap Nilai Perusahaan.

\section{Hubungan Perencanaan Pajak terhadap nilai perusahaan}

Hasil uji parsial t menjelaskan bahwa $\mathrm{H}_{2}$ diketahui nilai thitung sebesar 6,469ndengan nilai ttabel 1,994 dan nilai signifikansi 0,000 atau lebih kecil dari $\alpha=0,05(0,00<0,05)$ sehingga dapat disimpulkan $\mathrm{H}_{2}$ diterima yang artinya Perencanaan Pajak Berpengaruh signifikan terhadap Nilai Perusahaan. 


\section{Hubungan Corporate Social Responsibility dan Perencanaan Pajak Terhadap Nilai Perusahaan.}

Hasil uji simultan $\mathrm{F}$ menjelaskan bahwa $\mathrm{H} 3$ diketahui nilai $\mathrm{f}_{\text {hitung }}$ sebesar 21,028 dengan tingkat kesalahan 5\% dimana df $\left(\mathrm{n}_{1}\right)$ 3-1 = 2 dan $\mathrm{df}\left(\mathrm{n}_{2}\right)$ 72-3 = 69 maka diperoleh $\mathrm{f}_{\text {tabel }} \mathrm{df}\left(\mathrm{n}_{1}\right)$ dan df $\left(n_{2}\right) 69$ sebesar $f_{\text {hitung }}>f_{\text {tabel }}(21,028>3,12)$ dengan nilai signifikansi Nilai Perusahaan 0,000. Karena nilai signifikasi Nilai perusahaan lebih kecil dari $0,05(0,000<0,05)$, sehingga $\mathrm{H}_{3}$ diterima yang artinya Corporate Social Responsibility dan Perencanaan Pajak Berpengaruh terhadap Nilai Perusahaan.

\section{SIMPULAN}

Berdasarkan pembahasan dan hasil statistik dengan menggunakan program SPSS versi 25 yang telah dilakukan pada bab-bab sebelumnya, dapat ditarik kesimpulan bahwa hasil pengujian hipotesis pertama menunjukan bahwa Corporate Social Responsibility tidak berpengaruh terhadap Nilai Perusahaan. Hal ini dibuktikan bahwa nilai signifikansi 0,321 lebih besar dari $\alpha=$ $0,05(0,321>0,05)$ dengan demikian hipotesis $\mathrm{H}_{1}$ ditolak sehingga dikatakan bahwa bahwa Corporate Social Responsibility tidak berpengaruh terhadap Nilai Perusahaan.

Perencanaan Pajak berpengaruh terhadap Nilai Perusahaan. Hasil pengujian hipotesis kedua menunjukan bahwa Perencanaan Pajak berpengaruh positif terhadap nilai perusahaan. Hal ini dibuktikan dengan nilai signifikansi 0,000 atau lebih kecil dari $\alpha=0,05(0,00<0,05)$ dengan demikian hipotesis $\mathrm{H}_{2}$ diterima sehingga dikatakan bahwa Perencanaan Pajak Berpengaruh signifikan terhadap Nilai Perusahaan.

Corporate Social Responsibility dan Perencaan Pajak secara simultan berpengaruh terhadap Nilai Perusahaan. Hal ini dibuktikan nilai signifikasi Nilai perusahaan lebih kecil dari $0,05(0,000<0,05)$, dengan demikian $\mathrm{H}_{3}$ diterima sehingga dikatakan bahwa Corporate Social Responsibility dan Perencanaan Pajak secara simultan berpengaruh terhadap Nilai Perusahaan.

\section{DAFTAR PUSTAKA}

Adityo. (2012). Analisis Pengaruh Corporate Social Responsibility, Beta, Firm Size, dan Boook Market Ratio tehadap Return Saham (Studi Kasus Perusahaan Manufaktur yang Terdaftar di BEI Periode 2010 - 2011). Jurnal Akuntansi. Semarang : Fakultas Ekonomi Universitas Diponegoro.

Agus Harjito dan Martono, Manajemen Keuangan. Edisi Kedua, Cetakan Pertama, Penerbit EKONISIA, Yogyakarta, 2011.

Ambarwati, R,E., Wulandari, D. (2009). Asuhan Kebidanan Nifas. Jogjakarta: Mitra Cendika Press.

Ardianto,Elvinaro.,Machfudz. Didin.,M.2011.Efek kedermawanan pebisnis dan CSR. Jakarta: PT.Elex Media Komputindo

Barkemeyer, R. (2007). Legitimacy as a Key Driver and Determinant of CSR in Developing Countries. Paper for the 2007 Marie Curie Summer School on Earth System Governance, Amsterdam.

Boone dan Kurtz. 2007. Pengantar Bisnis Kontemporer. Edisi 11. Jakarta: Salemba Empat.

Brigham dan Houston. 2010. Dasar-dasar Manajemen Keuangan Buku 1 (Edisi 11). Jakarta : Salemba Empat.

Brigham, Eugene F dan Houston. 2006. Fundamental of FinancialManagement: Dasar-Dasar Manajemen Keuangan. Edisi 10. Jakarta: Salemba Empat.

Cahyonowati, dan Meilinda. 2013. Pengaruh Corporate Governance Terhadap Manajemen Pajak. Jurnal akuntansi. Vol. 2, No. 3 ISSN: 2337-3806.

Chariri, Anis dan Imam Ghazali. 2003. Teori Akuntansi. Semarang: Badan Penerbit Universitas Dipenogoro

Chen et al., (2010). Are Family Firms More Tax Aggressive Than Non-Family Firms Journal of Financial Economics, 41-61. 
Christiawan, Y.J., dan Tarigan J. (2007). Kepemilikan Manajeral: Kebijakan Hutang, Kinerja dan Nilai Perusahaan. Jurnal Akuntansi dan Keuangan. Universitas Kristen Petra. 9(1). PP 1-8

Crowther, David (2008) Corporate Social Responsibility. Gulen Aras \& Ventus Publishing Aps

Deegan, C. 2004. Financial Accounting Theory. McGraw-Hill Book Company. Sydney.

Deegan, Craig. 2000. Financial Accounting Theory. Australia NSW: McGrawHill

Derashid, C. dan Zhang, H. (2003). Effective Tax Rates and The Industrial Policy Hypothesis: Evidence from Malaysia. Dalam Journal of International Accounting, Auditing and Taxation, 12 (1): 45-62.

Dwi Ayuningtyas dan Kurnia. 2013. Pengaruh profitabilitas, kebijakan dividen, dan kesempatan investasi terhadap nilai perusahaan.

Dyreng, Scott D., Hanlon, Michelle., Maydew, Edward L. (2010). The Effect Of Corporate Tax Avoidance. The Accounting Review, 85, 1163-1189.

Edi. Suharto. 2007. Kebijakan Sosial Sebagai Kebijakan Publik. Bandung: Alfabeta

Estiasih,S.P,. 2015. pengaruh Corporate Social Responsibility, kepemilikan manajerial, kepemilikan institusional, dewan komisaris independen, komite audit terhadap nilai perusahaan dengan profitabilitas, ukiran perusahaan, kesempatan pertumbuhan sebagai moderating.

Florensia Jusny. 2015. Pengaruh Konservatisme Akuntansi Terhadap Nilai Perusahaan Dimoderasi oleh Good Corporate Governance (Studi Empiris Pada Perusahaan Sektor Retail Trade yang Listing di Bursa Efek Indonesia).

Fullerton (1983). Which Effective Tax Rate. Working Paper No. 1123. National Bureau of Economic Research. Wiley Finance.

Ghozali dan Chariri, 2007. Teori Akuntansi. Semarang: Badan Penerbit Undip

Ghozali, Imam. 2016. Aplikasi Analisis Multivariete Dengan Program IBM SPSS 23 (Edisi 8). Cetakan ke VIII. Semarang : Badan Penerbit Universitas Diponegoro.

Gray, et. al. 1995. Corporate Social and Environmental Reporting: A Review of Literature and a Longitudinal Study of UK Disclosure. Accounting, Auditing, and Accountability Journal Vol.8 No 2: 47-76.

Hackston, David and Markus J. Milne. 1996. Some Determinants of Social and Environmental Disclosure in New Zealand Companies. Accounting, Auditing and Accountability Journal. Vol. 9, No. 1, p. 77-108

Hadi, Nor. 2011. Corporate Social Responsibility. Yogyakarta: Graha Ilmu.

Hadi, Nor. 2014. Corporate Social Reponsibility. Yogyakarta: Graha Ilmu.

Hadianto, M. L. 2013. Analisis Pengaruh Kinerja Keuangan Terhadap Nilai Perusahaan Dengan Pengungakapan CSR dan GCG Sebagai Variabel Pemoderasi. Skripsi. Universitas Diponegoro. Semarang.

Harmoni, Ati dan Ade Andriyani.2008.Penilaian Konsumen terhadap Corporate Social Responsibility (CSR) perusahaan. Skripsi. Fakultas Ekonomi. Universitas Gunadarma. Depok

Harnanto. 2013. Perencanaan Pajak. Edisi Pertama. Yogyakarta: BPFE.

Hendrik, Budi Untung. 2008. Corporate Social Responsibility. Jakarta: Sinar Grafika.

Himatul Ulya. 2014. Analisis Pengaruh Kebijakan Hutang, Kebijakan Dividen, Profitabilitas, Kinerja Perusahaan dan Keputusan Investasi Terhadap Nilai Perusahaan pada Peruahaan Manufaktur yang Terdaftar di Bursa Efek.

Hui, F. dan G. Bowrey. (2008). "Corporate Social Responsibility Reporting in Hong Kong: Case Strudy of Three Note-issuing Banks (2003-2006)".

Indah Ayu Pusparini, Moch. Dzulkirom AR dan Devi Farah Azizah. 2013. Implementasi Tax Planning dalam Upaya Penghematan Pajak Penghasilan (PPh) Badan (Studi Kasus Pada PT. Citra Perdana Kendedes Malang.

Indrawan, Danu Candra. 2011. Pengaruh corporate social responsibility terhadap kinerja perusahaan. Skripsi Universitas Diponegoro: Semarang 
Khotimah, Khusnul. 2014. Pengaruh Perencanaan Pajak Terhadap Manajemen Laba. Jurnal Bisnis dan Manajemen. Vol.4, No.2, Agustus 2014.

Laras Surya Ramadhani.2012."Pengaruh Corporate Social Responsibility Terhadap Nilai Perusahaan dengan Prosentase Kepemilikan Manajemen Sebagai Variabel Moderating Pada Perusahaan Manufaktur yang Terdaftar di BEI

Lestari. 2014. Pengaruh Perencanaan Pajak Terhadap Nilai Perusahaan Dengan Moderasi Corporate Governance.

Mangoting, Yenni. 1999. Tax Planning: Sebuah Pengantar sebagai Alternatif Meminimalkan Pajak. Jurnal Akuntansi dan Keuangan. Universitas Kristen Petra.

Mardiasmo, 2009, Akuntansi Sektor Publik, Yogyakarta: Andi.

Mardiasmo. 2016. Perpajakan Edisi Revisi Tahun 2016. Yogyakarta:Penerbit Andi.

Margaretha, Farah. 2014. Dasar-dasar Manajemen Keuangan. Jakarta: PT Dian Rakyat.

Mohamad Zain. 2007. Manajemen Perpajakan, Salemba empat, jakarta.

Mohammad Zain. 2003. Manajemen Perpajakan. Jakarta : Salemba Empat.

Nguyen, D., Leung, K., McIntyre, L., Ghali, W., Sauve, R. Does Integrated Management of Childhood Illness (IMCI) training improve the skills of health workers? A systematic review and meta analysis. PLoS ONE 8[6]. 2013.

Nike, dkk. 2013. Pengaruh Perencanaan Pajak Dan Corporate Governance Terhadap Nilai Perusahaan.

Nurlela dan Islahuddin. 2008. Pengaruh Corporate Social Responsibility Terhadap Nilai Perusahaan Dengan Prosentase Kepemilikan Manajemen Sebagai Variabel Moderating (Studi Empiris Pada Perusahaan Yang Terdaftar Di Bursa Efek Jakarta). Simposium Nasional Akuntansi XI. 23-24 Juli 2008. Pontianak.

O'Donovan, 2002. Environmental Disclosure in the Annual Report: Extending the Applicability and Predictive Power of Legitimacy Theory, Accounting, Auditing and Accountability Journal, Vol.15, No.3,pp.344-371.

Perdana. 2014. Pengaruh Perencanaan Pajak Dan Mekanisme Corporate Governance Terhadap Nilai perusahaan

Pohan, Chairil Anwar. (2013). Manajemen Perpajakan Strategi Perencanaan Pajak dan Bisnis. Gramedia Pustaka Utama. Jakarta.

Purwono dan Hartono, R. 2011. Bertanam Jagung Unggul. Penebar Swadaya. Jakarta.

Resmi, Siti. 2014. Perpajakan Teori dan Kasus, Buku 1 edisi 8. Salemba Empat. Jakarta.

Riswari, D.A., \& Cahyonowati, N. (2012). Pengaruh Corporate Social Responsibility terhadap Nilai Perusahaan dengan Corporate Governance sebagai Variabel Moderating (Studi pada Perusahaan Publik Non Finansial yang Tercatat di Bursa Efek Indonesia Tahun 20082009). Jurnal Akuntansi, Vol. 1 No. 1. Hal. 1-12. Semarang : UNDIP.

Rustriarini, Ni Wayan. 2010. "Pengaruh CorporateGorvernance Pada Hubungan CorporateSocial Responsibility dan NilaiPerusahaan". Simposium NasionalAkuntansi XIII Purwokerto.

Saridewi,S.P., Susila,G.P.A, dan Yudiaatmaja,F. 2016. pengaruh profitabilitas dan Corporate Social Responsibility(CSR) terhadap nilai perusahaan pada perusahaan sektor barang konsumsi yang terdaftar di BEI periode 2012-2014.

Sayekti, Y. dan L. S. Wondabio. 2007. "Pengaruh CSR Disclosure terhadap Earning Response Coefficient". Simposium Nasional Akuntansi X. Makassar, 26-28 Juli.

Siregar, Syofian. 2016. Statistika Deskriptif Untuk Penelitian. Jakarta: PT Rajagrafindo Persada. Siregar. 2016. Pengaruh Corporate Social Responsibility terhadap Nilai Perusahaan dengan Profitabilitas sebagai Variabel Moderating Pada Perusahaan Pertambangan yang Terdaftar di Bursa Efek Indonesia.

Soemitro, Rochmat. 2009. Asas dan Dasar Perpajakan. Bandung : Refika Aditama.

Sophar Lumbantoruan. 1996. Akuntansi Pajak, Edisi Revisi, Jakarta: Penerbit Gramedia.

Suandy, Erly. 2011. Hukum Pajak, Edisi 5, Jakarta Salemba Empat. 
Sugiyono. 2015. Metode Penelitian Pendidikan (Pendekatan Kuantitatif, Kualitatif dan R\&D). Penerbit CV. Alfabeta: Bandung.

Sugiyono. 2016. Metode Penelitian Kuantitatif, Kualitatif dan R\&D. Bandung: PT Alfabet.

Sujoko dan Ugy Soebiantoro. 2007. Pengaruh Struktur Kepemilikan Saham, Leverage, Faktor Interen dan Faktor Eksteren terhadap Nilai Perusahan. Jurnal Manajemen dan Kewirausahaan. Vol 9, No. 1.

Taridi, Tirmidzi.2009. "Perkembangan Good Corporate Governance Di Indonesia". Yogyakarta. Ullman, 1989, Ullman's Encyclopedia of Indutrial Chemistry, Vol. A-16, Interscience Encyclopedia, Inc., New York.

Untung Wahyudi dan Hartini Prasetyaning Pawestri, (2006), Implikasi Struktur Kepemilikan terhadap Nilai Perusahaan: dengan Keputusan Keuangan Sebagai Variabel Intervening, Simposium Nasional Akuntansi 9 Padang.

Waryanti, 2009. Pengaruh Karakteristik Perusahaan Terhadap Pengungkapan Sosial Pada Perusahaan Manufaktur di Bursa Efek Indonesia. Skripsi S1 Akuntansi UNDIP

Waryanto. (2010). Pengaruh Karakteristik Good Corpoate Governance (GCG) Terhadap Luar Pengungkapan Corporate Social Responsibility di Indonesia. Skripsi. Universitas Diponegoro.

Wijaya, Anthony dan Linawati, Nanik 2015 “ Pengaruh Kinerja Keuangan Terhadap Nilai Perusahaan ".

www.antaranews.com/berita/412361/sektor-perkebunan-sumbang-devisa-214-miliar-dolar-as www.finance.detik.com

www.globalreporting.org

www.idx.co.id.

www.koran- sindo.com

www.pajak.go.id

www.quote.kontan.co.id

www.Surabaya.tribunnews.com 